HePG Plant Science Toolay

Research Communication

\title{
Leucobryum aduncum var. scalare (Leucobryaceae: Bryophyta) - new to the Eastern Ghats
}

\author{
P.M. Biju and A.E.D. Daniels
}

Bryology Laboratory, Department of Botany \& Research Centre, Scott Christian College (Autonomous), Nagercoil - 629 003, India

Article history

Received: 16 February 2017

Accepted: 16 March 2017

Published: 05 April 2017

(C) Biju and Daniels (2017)

Editor

K. K. Sabu

Publisher

Horizon e-Publishing Group

Correspondence

P.M. Biju

$\square_{\text {p.m.biju1979@gmail.com }}$

A.E.D. Daniels

区dulipdaniels@yahoo.co.uk

\begin{abstract}
Leucobryum aduncum var. scalare, so far known from the Northeast and the Western Ghats for India, is added here to the moss flora of the Eastern Ghats. A detailed description with figures substantiated by a photo plate and a key to distinguish the species of Leucobryum Hampe from the region.
\end{abstract}

\section{Keywords}

Bryophyta; Eastern Ghats; Leucobryaceae; Leucobryum aduncum var. scalare

Biju, P. M. and Daniels, A. E. D. 2017. Leucobryum aduncum var. scalare (Leucobryaceae: Bryophyta) - new to the Eastern Ghats. Plant Science Today 4(2): 64-67. http://dx.doi.org/10.14719/pst.2017.4.2.295

\section{Introduction}

In India, Leucobryum Hampe is represented by nine species (Lal, 2005; Daniels, 2010; Dandodiya et al., 2011). Of these, seven have been reported from the Western Ghats. However, only two species, $L$. humillimum (Besch.) Cardot (L. cucullifolium Cardot, now a synonym of $L$. humillimum) and $L$. juniperoideum (Brid.) Müll.Hal., have so far been reported from the Eastern Ghats (Satish et al., 2014).

Indian bryophytes have still not received the due attention they deserve and therefore, information on their taxonomy and distribution is far from adequate. Many regions rich in bryophyte diversity remain un/underexplored, one being the
Eastern Ghats. Hence, surveys were initiated a couple of years ago in Kolli Hills of Eastern Ghats. As a result, one species of the genus Leucobryum, $L$. aduncum Dozy \& Molk. var. scalare (Müll.Hal. ex M. Fleisch.) A. Eddy, so far known from the Northeast and the Western Ghats in India, was collected from the Kolli Hills which is incidentally a new record for the Eastern Ghats. The species is described and illustrated in detail, substantiated by a taxonomic key including both the earlier reported species and a photographic plate for easy identification of the species. The present addition raises the number of species in the Eastern Ghats to three. The specimen is housed at the herbarium of Scott Christian College (SCCN). 

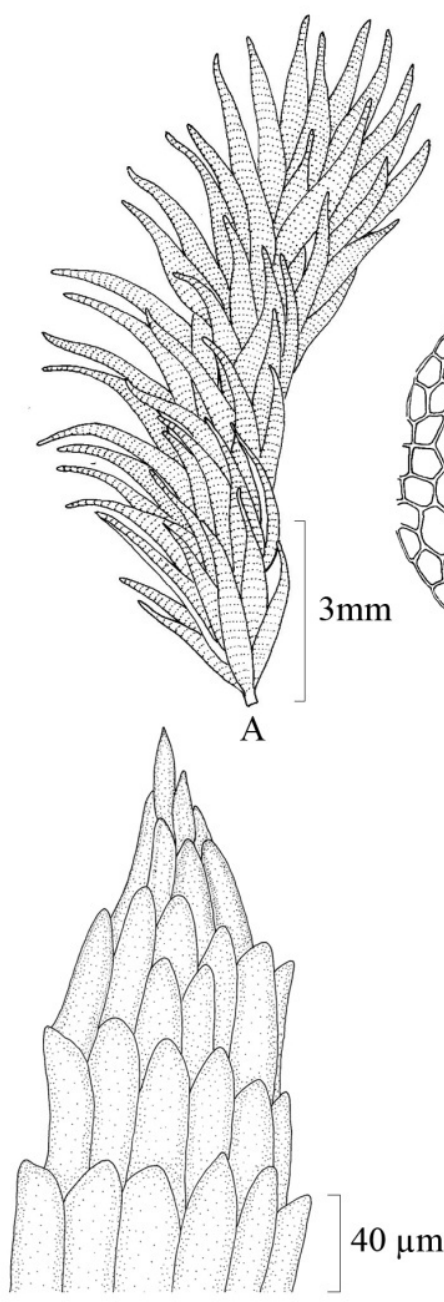

E

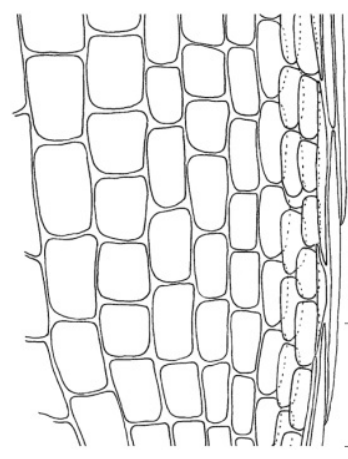

$\mathrm{F}$

$40 \mu \mathrm{m}$

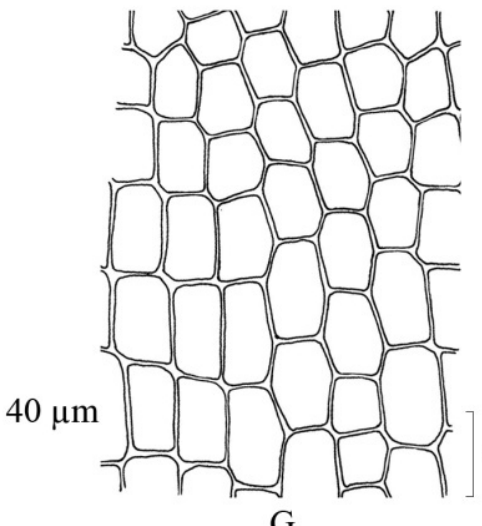

G
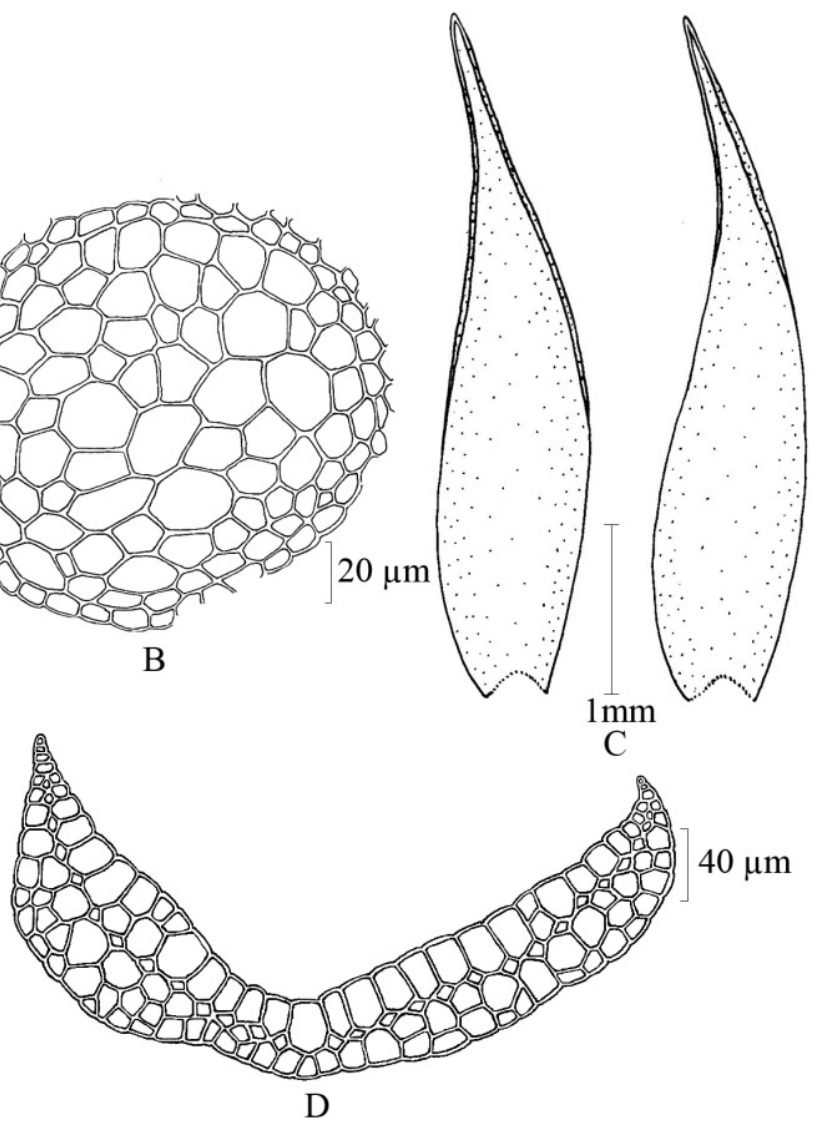

Fig. 1. Leucobryum aduncum Dozy \& Molk. var. scalare (Müll.Hal. ex M. Fleisch.) A. Eddy

A. Plant B. Cross section of stem C. Leaves D. Cross section of leaf E. Leaf apical cells

F. Leaf median cells at margin G. Leaf median cells H. Leaf basal cell (Biju 1566 p.p.) 

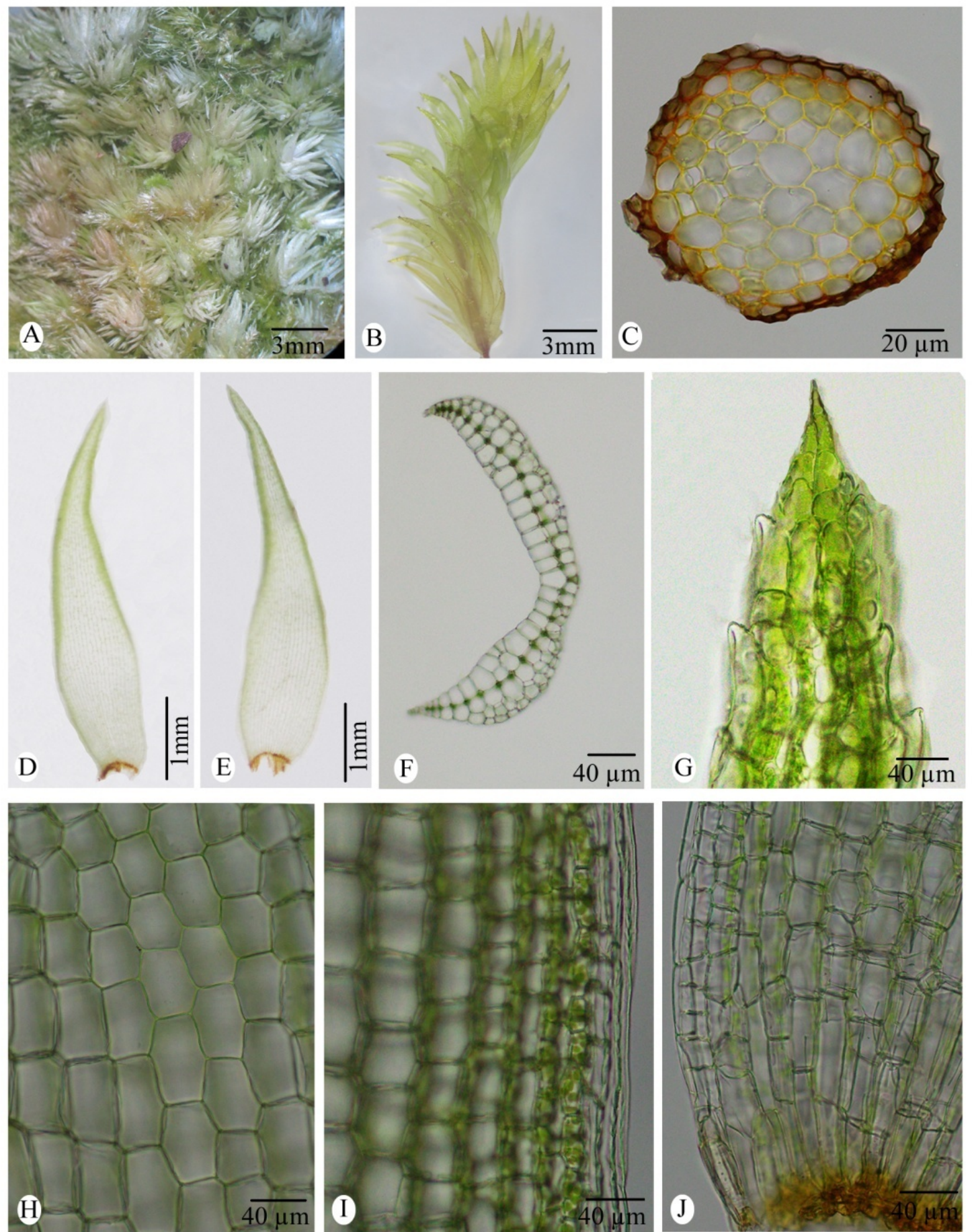

Fig. 2. Leucobryum aduncum Dozy \& Molk. var. scalare (Müll.Hal. ex M. Fleisch.) A. Eddy A. Habit B. Plant C. Cross section of stem D \& E. Leaves F. Cross section of leaf G. Leaf apex H. Leaf median cells I. Leaf hyaline cells at margin J. Leaf basal cells 


\section{Key to the species}

1a. Stems with a central strand; leaves flexuose, cucullate, acute, closed at apex

\section{L. humillimum}

b. Stems without a central strand; leaves rigid, concave, canaliculate, open at apex

\section{2}

2a. Leaves smooth on back L. juniperoideum

b. Leaves raised-scabrous on back

\section{L. aduncum var. scalare}

Leucobryum aduncum Dozy \& Molk. var. scalare (Müll.Hal. ex M. Fleisch.) A. Eddy, Handb. Males. Moss. 2: 11. 1990. Leucobryum scalare Müll.Hal. ex M. Fleisch., Musci Buitenzorg 1: 143. 1904. - Types: the Philippines, Luzon, Benguet, 5000 ft., Micholitz 173 (BM, FH); Indonesia, Tjibodas, 1450 m (F); Sumbawa, 1200 m, Warburg s.n. (OXF, BM). (Figs. 1 \& 2)

Plants 1 - $2 \mathrm{~cm}$ tall, glaucous-green, browntinged above, white below. Stems branched or not, ca $0.20 \times 0.18 \mathrm{~mm}$ in cross section, ovate, without a central strand; cortex 2- or 3-layered; cells $8-12 \times$ 4 - $8 \mu \mathrm{m}$, thick-walled; medullary ones 16 - $32 \times 12$ $24 \mu \mathrm{m}$, quadrate-hexagonal, thin-walled. Leaves erectopatent to patent, falcate to falcato-secund when dry, 3 - $3.2 \times 0.8-1 \mathrm{~mm}$, oblong-lanceolate, raised-scabrous abaxially, canaliculate at apex, with 1 layer of chlorocysts between 2 layers of leucocysts above in cross section, becoming 3- or 4layered below; apical cells $56-64 \times 12-24 \mu \mathrm{m}$; median cells $32-72 \times 28$ - $36 \mu \mathrm{m}$; basal cells $20-40$ $\times 12$ - $20 \mu \mathrm{m}$; hyaline marginal cells 3 - to 6-rowed at middle with distinctly nodulose and pitted walls, becoming 1-rowed above and 3-rowed below; inner ones $10-32 \times 10-16 \mu \mathrm{m}$; those at the outermost 2 rows $80-160 \times 8-12 \mu \mathrm{m}$, narrow, elongate; leucocysts $24-36 \times 20-32 \mu \mathrm{m}$, rectangular; costa broad, raised-scabrous abaxially. Sporophyte not seen.

Habitat: Lignicolous, in plantations, ca $1200 \mathrm{~m}$.

Distribution: India: Northeast India (Manipur), [Western Ghats of Kerala and Tamil Nadu, Eastern Ghats (Tamil Nadu - Kolli Hills)], Cambodia, China, Fiji, Indonesia, Malay Peninsula, Myanmar, New Caledonia, New Guinea, the Philippines, Sri Lanka, Thailand and Vietnam.

Specimens examined: Eastern Ghats: Tamil Nadu, Namakkal Dist., Kolli Hills, Perumakka Shola, ca 1200 m, 21.1.2016, P.M. Biju 1566 p.p.

\section{Discussion}

The Eastern Ghats is a least-explored region in terms of bryophyte diversity which is evident by the number of new reports made by Kumar and Krishnamurthy (2007), Sathish et al. (2014), Biju and Daniels (2016), and Palani et al. (2017). The present report supports this fact as Leucobryum aduncum var. scalare is being reported as new to the bryoflora of the Eastern Ghats. Almost all the species so far reported from the Eastern Ghats are already known from the Western Ghats as well (Daniels, 2010). This similarity in the distribution of species in both regions might reflect their geological past.

\section{Acknowledgements}

We thank the Tamil Nadu State Forest Department for permission to explore the study area and help in the field. AEDD thanks the Ministry of Environment, Forests \& Climate Change, Govt. of India, New Delhi, for financial assistance, and the Principal, Scott Christian College, for facilities.

\section{References}

Biju, P. M. and A. E. D. Daniels 2016. Two species of Isopterygium Mitt. - New to the Eastern Ghats in Peninsular India. Pl. Sci. Today 3: 129-134. https://doi.org/10.14719/pst.2016.3.2.223

Dandotiya, D., H. Govindapyari, S. Suman, and P. L. Uniyal 2011. Checklist of the bryophytes of India. Arch. Bryol. 88: 1-126.

Daniels, A.E.D. 2010. Checklist of the bryophytes of Tamil Nadu. Arch. Bryol. 65: 1-118.

Kumar, G. V. and K. V. Krishnamurthy 2007. Moss flora of Shervaroy Hills of Eastern Ghats (South India). In: Nath, V. \& A.K. Asthana (eds.), Current Trends in Bryology. Bishen Singh Mahendra Pal Singh, Dehra Dun. p. 227-243.

Lal, J. 2005. A checklist of Indian mosses. Bishen Singh Mahendra Pal Singh, Dehra Dun, India. 164 pp.

Sathish, S. S., T. Thamizharasi, R. Palani, P. Vijayakanth, and A. Vimala 2014. Checklist of mosses (Bryopsida) of the Kalrayan Hills in the Eastern Ghats of Tamil Nadu, India. Eng. Biosci. 2: 28-33.

Palani, R., S. S. Sathish, T. Thamizharasi and P. Vijayakanth 2017. Checklist of Mosses (Bryophyta) of Bodamalai Hills in Eastern Ghats, Tamil Nadu. Pl. Sci. Today 4: 49-54. https://doi.org/10.14719/pst.2017.4.1.278 